\title{
The Measurement of Firm Performance
}

\author{
Nyoman Ayu Shandy Catarina \\ E-mail : Shandycatarina@gmail.com
}

\section{Cara perusahaan mengukur kinerjanya atau keberhasilannya}

Menurut jurnal Cong Fenga, Pankaj C. Patelb , K. Sivakumarc, kinerja perusahaan berhubungan positif dengan ruang lingkup internasional melalui adanya chief global officers (CGOs). CGO berkontribusi secara positif terhadap kinerja perusahaan dan secara signifikan memediasi hubungan antara penyebaran penjualan geografis dan kinerja perusahaan. (Feng, Patel, \& Sivakumar, 2020)

Menurut jurnal Yonghong Liu, Lijun Lei, E. Holly Buttner, penelitian ini berkontribusi pada literatur tentang keragaman gender, kepemimpinan perempuan, tata kelola pada perusahaan, dan tanggung jawab pada sosial perusahaan teori peran sosial serta teori tentang stakeholder yang berteori bahwa memiliki lebih banyak perempuan di ruang dewan secara signifikan meningkatkan keterlibatan strategis dewan dalam CSR, yang kemudian berkontribusi untuk kinerja perusahaan. (Liu, Lei, \& Buttner, 2020)

Penelitian menemukakan efek signifikan pada hubungan antara pengungkapan CSR dan kinerja perusahaan. Integritas CEO merupakan faktor penting yang memoderasi efektivitas pengungkapan CSR untuk membangun reputasi perusahaan. Peran integritas CEO dalam mendorong kredibilitas pengungkapan CSR yang disoroti oleh Abernathy et al. (2017) dalam tinjauan literatur mereka tentang hubungan antara pengungkapan CSR dan kinerja perusahaan. (Pham \& Tran, 2020)

Hubungan yang kuat antara kolaborasi dan kinerja perusahaan. Kolaborasi antar perusahaan dapat meningkatkan efek positif pada profitabilitas perusahaan. Efek ini meningkat lebih jauh jika perusahaan mulai berkolaborasi dengan perusahaan lain. (Moaniba, Su, \& Lee, 2020)

\section{Persamaan pendekatan subyektif dalam mengamati kinerja perusahaan}

Dalam jurnal Pratono, A.H. (2016) dan Pratono, et al. (2019) terdapat persamaan pendekatan subyektif melalui pembelajaran antar organisasi yang memberi efek positif terhadap hubungan antar orientasi kewirausahaan. Sedangkan perbedaannya, dalam jurnal Achieving sustainable competitive advantage through green entrepreneurial orientation and market orientation menggunakan pendekatan green entrepreneurial orientation (GEO) untuk mengamati kinerja perusahaan sedangkan pada jurnal Strategic orientation and information technological turbulence Contingency perspective in SMEs menggunakan teori strategic orientation (SO). (Pratono , Darmasetiawan, Yudiarso, \& Jeong, 2019) (Pratono, Strategic orientation and information technological turbulence: Contingency perspective in SMEs, 2016). 
Bibliography

Feng, C., Patel, P. C., \& Sivakumar, K. (2020). Chief global officers, geographical sales dispersion, and firm performance. Journal of Business Research, 121, 58-72.

Liu, Y., Lei, L., \& Buttner, E. H. (2020). Establishing the boundary conditions for female board directors' influence. Journal of Business Research, 121, 112-120.

Moaniba, I. M., Su, H.-N., \& Lee, P.-C. (2020). Geographic distance between co-inventors and firm performance: The. Technological Forecasting \& Social Change, 157, 120070.

Pham, H. S., \& Tran, H. T. (2020). CSR disclosure and firm performance: The mediating role of corporate. Journal of Business Research, 120, 127-136.

Pratono , A. H., Darmasetiawan, N. K., Yudiarso, A., \& Jeong, B. G. (2019). Achieving sustainable competitive advantage through green entrepreneurial orientation and market orientation: The role of inter-organizational learning. 32 No. 1, 2-15.

Pratono, A. H. (2016). Strategic orientation and information technological turbulence: Contingency perspective in SMEs. Business Process Management Journal, 22(2), 368-382. 